\title{
Major, trace element and stable isotope geochemistry of synorogenic breccia bodies, Ellsworth Mountains, Antarctica
}

\author{
J. P. Craddock, M. S. McGillion, and G. F. Webers \\ Geology Department, Macalester College, St. Paul, MN 55105 USA
}

\begin{abstract}
Cambrian carbonates in the Heritage Range of the Ellsworth Mountains, West Antarctica host a series of carbonate-rich breccia bodies that formed contemporaneously with the Permian Gondwanide orogen. The breccia bodies had a three-stage genesis, with the older breccias containing Cambrian limestone (and marble) clasts supported by calcite, whereas the younger breccias are nearly clast-free and composed entirely of matrix calcite. Breccia clasts, calcite matrix and detrital matrix samples were analyzed using x-ray fluorescence (major and trace elements), $\mathrm{x}$-ray diffraction, and stable isotopes $(\mathrm{C}, \mathrm{O})$ and suggest that the breccias formed as part of a closed geochemical system, at considerable depth, within the Cambrian limestone host as the Ellsworth Mountains deformed into a fold-and-thrust belt along the margin of Gondwana.
\end{abstract}

Citation: Craddock, J.P., M.S. McGillion, and G.F. Webers (2007), Major, trace element and stable isotope geochemistry of synorogenic breccia bodies, Ellsworth Mountains, Antarctica, in Antarctica: A Keystone in a Changing World - Online Proceedings of the $10^{\text {th }}$ ISAES, edited by A.K. Cooper and C.R. Raymond et al., USGS Open-File Report 2007-1047, Short Research Paper 078, 3 p.; doi:10.3133/of2007-1047.srp078

\section{Introduction}

Breccia formation in thin-skinned thrust belts is usually associated with displacement on fault surfaces and is not lithology-dependent. The breccias in the southern Heritage Range of the Ellsworth Mountains, West Antarctica are not planar, fault-related breccias but rather a three-phase progression of breccia body formation contained within the middle Cambrian Minaret Fm. limestones. The field relations of the breccias have been described at length by Sporli et al. (1992) and are reviewed here briefly. The oldest breccia bodies are large, irregularly shaped, randomly oriented and rich in limestone clasts supported in a calcite matrix. The intermediate breccias are smaller, more cylindrical in shape, tend to have margins that are cleavage or bedding planes and are more calcite matrix-rich (Fig. 1a). The youngest breccias are mostly cylindrical, cross-cut both earlier breccia types and are clast-free (Fig 1b). Where clasts are present they are locally-derived Minaret Fm. limestones and marbles (some are mylonitic), which contain the Gondwanide axial-planar cleavage; some are bedded. Many breccia margins appear leached and discolored. Detrital deposits are present in the breccias, some appearing as small channel deposits, often with local cross-bedding. Some breccias are contemporaneous and are cross-cut by Gondwanide thrust faults, and are offset toward the northeast on southwest-dipping thrusts. Internally, all the calcite, clasts and younger matrix, contain two sets of mechanical twins indicating preservation of some tectoni $\mathrm{c}$ deformation. In outcrop, it appears that the entire breccia system involves nothing but calcite and dolomite. This effort was intended to characterize the origin of the breccias by analyzing their geochemistry, an effort limited by a small sample suite.

\section{Methods}

Samples were observed petrographically, and powders were prepared for X-ray diffraction (5 samples, Macalester College), X-ray fluorescence (5 samples,

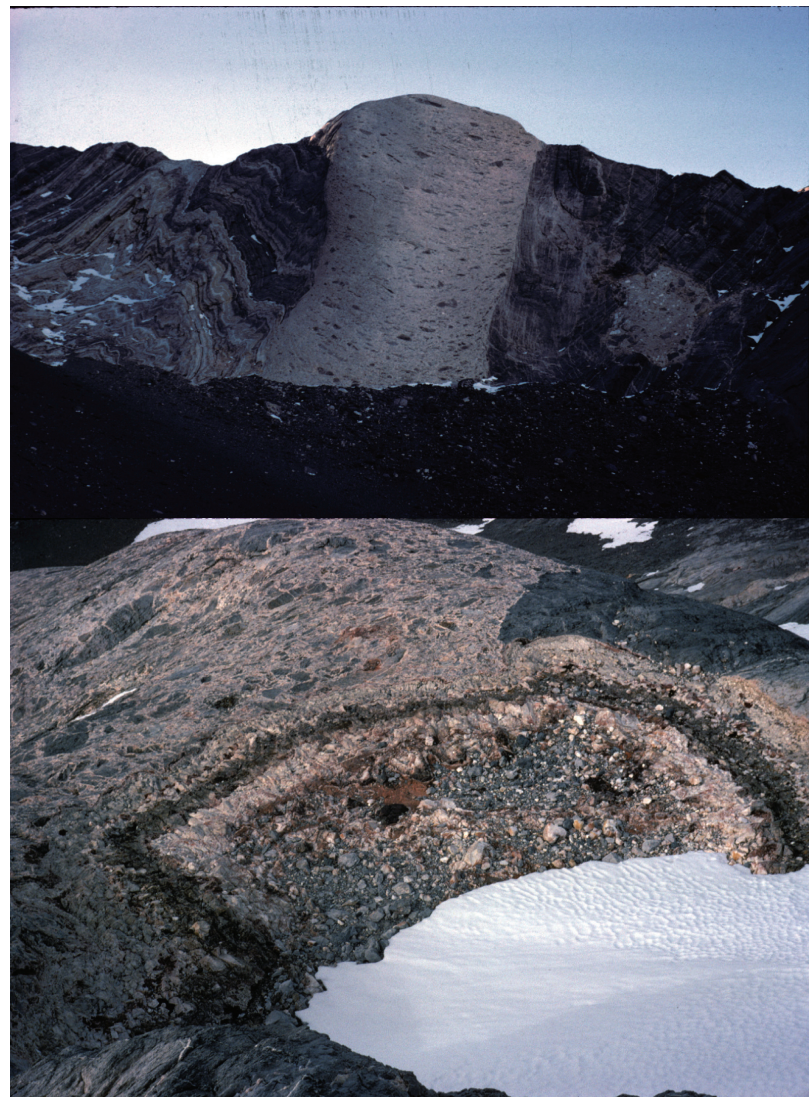

Figure 1. (a): The 'type' breccia body in the Independence Hills is a vertical cylinder (100 m high) with internal layering and with margins parallel to the sub-vertical axial-planar cleavage. Note horizontal, cylindrical breccia body on right; both cross-cut folds in the Cambrian Minaret Fm. (b; lower) A type 2 breccia cut by a cylindrical, matrix-free breccia pipe (diameter $=3$ meters). 
Table 1 Major elements (wt \%); trace elements (ppm) of breccia components

\begin{tabular}{|c|c|c|c|c|c|c|c|c|c|c|c|c|c|c|c|}
\hline $\begin{array}{l}\text { Major } \\
\text { Elements } \\
\text { Sample }\end{array}$ & $\mathrm{SiO2}$ & TiO2 & Al2O3 & $\mathrm{Fe} 2 \mathrm{O3}$ & MnO & MgO & $\mathrm{CaO}$ & $\mathrm{Na2O}$ & K2O & P2O5 & $\mathrm{BaO}$ & $\mathrm{Cr} 2 \mathrm{O3}$ & $\mathrm{Ce}$ & Co & $\mathbf{C u}$ \\
\hline LS Clast & 1.10 & 0.01 & 0.19 & 0.14 & 0.01 & 0.27 & 51.73 & 0.00 & 0.06 & 0.01 & int & 0 & 1 & 5 & 50 \\
\hline $\begin{array}{l}\text { Red } \\
\text { matrix }\end{array}$ & 5.00 & 0.06 & 1.40 & 6.63 & 0.04 & 0.23 & 45.45 & 0.00 & 0.18 & 0.08 & int & 0 & 67 & 4 & 40 \\
\hline $\begin{array}{l}\text { Calcite } \\
\text { Matrix }\end{array}$ & 0.07 & 0.01 & 0.09 & 0.03 & 0.00 & 0.02 & 51.75 & 0.00 & 0.03 & 0.00 & int & 0 & 20 & 6 & 44 \\
\hline $\begin{array}{l}\text { White } \\
\text { Matrix }\end{array}$ & 5.02 & 0.06 & 1.17 & 0.27 & 0.01 & 0.30 & 50.18 & 0.00 & 0.27 & 0.02 & int & 0 & 35 & 6 & 28 \\
\hline $\begin{array}{c}\text { Red } \\
\text { Matrix }\end{array}$ & 2.41 & 0.04 & 1.16 & 1.40 & 0.05 & 0.17 & 47.29 & 0.05 & 0.10 & 0.02 & int & 0 & 45 & 2 & 38 \\
\hline
\end{tabular}

$\begin{array}{ccccccccccccccc} & \mathbf{N i} & \mathbf{S c} & \mathbf{G a} & \mathbf{N b} & \mathbf{P b} & \mathbf{R b} & \mathbf{S r} & \mathbf{T h} & \mathbf{U} & \mathbf{Z r} & \mathbf{V} & \mathbf{Z n} & \text { LOI } & \text { Total } \\ \text { LS Clast } & 6 & 10 & 0 & 2 & 6 & 1 & 213 & 0 & 0 & 23 & 9 & 8 & 42.76 & 96.29 \\ \quad \text { Red } & 34 & 9 & 1 & 4 & 22 & 11 & 46 & 8 & 0 & 38 & 19 & 121 & 37.44 & 96.54 \\ \begin{array}{c}\text { Matrix } \\ \text { Cacite }\end{array} & 5 & 11 & 0 & 2 & 4 & 0 & 16 & 0 & 0 & 23 & 2 & 20 & 42.86 & 94.87 \\ \begin{array}{c}\text { Matrix } \\ \begin{array}{c}\text { White } \\ \text { Matrix }\end{array}\end{array} & 8 & 8 & 1 & 4 & 19 & 10 & 54 & 6 & 0 & 36 & 15 & 93 & 40.74 & 98.07 \\ \quad \text { Red } & 12 & 13 & 0 & 3 & 7 & 5 & 71 & 0 & 0 & 29 & 14 & 56 & 41.62 & 94.34 \\ \text { Matrix } & & & & & & & & & & & & & \end{array}$

McGill University), and stable isotope (6 samples, University of Minnesota) analysis. Samples include the Minaret clasts, breccia calcite matrix and breccia detrial units.

\section{Results}

Thin section and X-ray analysis of the various breccia materials identified calcite with minor amounts of dolomite $(1 \%)$, quartz (1\%) and hematite $(4 \%$, red matrix only). All the samples had considerable loss on ignition (LOI; 37-42\%), and concentrations of major and trace elements that are consistent, broadly, with a marine limestone XRF analysis (Table 1). Stable isotope $(\mathrm{O}, \mathrm{C})$ analyses revealed a consistent signature for the Minaret limestones, but the breccia matrix calcite is depleted: breccia matrix calcite $\left(7.48,7.69,5.87 \quad \delta^{18} \mathrm{O}\right.$ (SMOW) and $0.24,-0.57,-4.14 \quad \delta^{13} \mathrm{C}(\mathrm{PDB}) ;$ Minaret limestone $18.81 \delta^{18} \mathrm{O}$ (SMOW), $3.88 \delta^{13} \mathrm{C}$ (PDB), oolitic Minaret limestone $21.55 \quad \delta{ }^{18} \mathrm{O}$ (SMOW), $0.75 \delta^{13} \mathrm{C}$ (PDB), mylonitic Minaret marble $21.60 \delta{ }^{18} \mathrm{O}$ (SMOW), 0.77 $\delta^{13} \mathrm{C}(\mathrm{PDB})$.

\section{Discussion and conclusions}

The 'type' breccia body shape (Fig. 1a) suggests an igneous origin for these carbonate-rich, carbonate-hosted structures. Carbonatites are usually associated with rift tectonic settings, and are complex alkaline melts with mineral assemblages that include calcite, dolomite, and ankerite, as carbonate phases, and clinopyroxene, biotite, apatite and magnetite, and have fairly distinctive major and trace element concentrations. These breccias do not contain any silicate minerals and, for instance, have concentrations of $\mathrm{TiO}_{2}, \mathrm{MgO}$ and $\mathrm{P}_{2} \mathrm{O}_{5}$ that are $\sim 10, \sim 60$ and $\sim 50$ times lower than the average carbonatite. Trace elements (e.g., Th, Y, Ce, Zr) in the breccias are 10-75 times lower than in the average carbonatite. Both the major and trace element concentrations are comparable within the range of limestone compositions. Carbonatite calcites have $\delta^{18} \mathrm{O}(\mathrm{SMOW})$ and $\delta^{13} \mathrm{C}(\mathrm{PDB})$ values of 6.6-7.6 and -2 to -8 , respectively, whereas marine limestones are $\sim 31$ and 0 . The Minaret limestones are depleted but in the range of limestones. The matrix calcite is very depleted and suggestive of a hydrothermal or carbonatitic source.

Field and cross-cutting relations support a synorogenic origin for the breccia bodies in the late Permian. The breccia geochemistry suggests a closed carbonate-calcite system existed during the Gondwanide deformation and that hydrothermal fluids flowed within the closed Minaret Fm. portion of the thick Ellsworth section (Buggisch and Webers, 1992) dissolving and reprecipitating calcite in a continuum of three breccia phases. There are no void spaces in any of the breccia bodies so this was not an open system (i.e., karst), and breccia matrix calcite fluid inclusion homogenization temperatures $\left(160^{\circ}\right.$; Sporli et al., 1992) support a considerable depth for these rocks at 
the time of breccia formation. The Ellsworth Mountains were uplifted in the Cretaceous, exposing the breccias, based on the fission tracks studies of Fitzgerald and Stump (1991).

Acknowledgements. Samples were collected by Tom Bastien and Bernie Sporli (1963-4), John \& Cam Craddock and Jerry Webers (197980 ) and funded by NSF. Macalester College honors theses on these rocks were completed by John Craddock (1980) and Michael McGillion (1994). Portions of this were presented at a NSF-OPP Ellsworth Mountains proposal workshop organized by Craddock \& Webers in 1994. Reviews by John Splettstoesser and Bob Rutford are appreciated.

\section{References}

Buggisch, W. and Webers G.F., 1992, Facies of Cambrian carbonate rocks, Ellsworth Mountains, West Antarctica: Geological Society of America Memoir 170, p, 81-100.
Craddock, J.P. and Webers, G.F., 1981, Probable cave deposits in the Ellsworth Mountains of West Antarctica: Proceedings of the 8 th International Conference on Speleology, v. 1, p. 395-397.

Craddock, J.P., Craddock, J.C., Rutford, R.H., Sporli, K.B. and Webers, G.F., 1991, Synorogenic breccias in Cambrian Limestones, Southern Ellsworth Mountains, Antarctica: Gondwana 8 Proceedings, Hobart, Tasmania, p. 20.

Fitzgerald, P.G., and Stump, E., 1991, Early Cretaceous uplift in the Ellsworth Mountains of West Antarctica, Science, v. 254, p.92-94.

Sporli, K.B., Craddock, C., Rutford, R.H. and Craddock, J.P., 1992, Tectonic breccias in Cambrian limestones, Ellsworth Mountains, Antarctica: Geological Society of America Memoir 170. , p. 365-374.

[An updated bibliography on the Ellsworth Mountains is maintained at: www.macalester.edu/ craddock/paper/EWMRefs.doc ]. 